\title{
Susceptibility to misinformation: a study of climate change, Covid-19, and artificial intelligence
}

\author{
Sven Grüner \\ Martin-Luther-University Halle-Wittenberg \\ Contact: sven.gruener@landw.uni-halle.de
}

This version: 5.1.2021

\begin{abstract}
$\underline{\text { Abstract }}$
This study explores whether susceptibility to misinformation is context dependent. We conduct a survey experiment in which subjects had to rate the reliability of several statements in the fields of climate change, Covid-19, and artificial intelligence. There is some evidence for a monological belief system, i.e., being susceptible to one statement containing misinformation is correlated with falling to other false news stories, in all three contexts. The main findings to explain the susceptibility to misinformation can be summarized as follows: trust in social networks is positively associated with falling for misinformation in all contexts. There are also several context-related differences: Individuals are less likely to be susceptible to misinformation in the contexts of climate change and Covid-19 if they have a higher risk perception, tend to take a second look at a problem (i.e., willingness to think deliberately), update their prior beliefs to new evidence (actively open-minded thinking), and trust in science and mass media. Within the context of artificial intelligence, being less prone to conspiracy theories in general and lower subjective knowledge helps not to be susceptible to misinformation.
\end{abstract}

\section{$\underline{\text { Keywords }}$}

False news stories, monological belief system, Covid-19, climate change, artificial intelligence 


\section{Introduction}

Starting with the 2016 U.S. election campaign, psychologists and economists have been systematically studying the influence of false news stories (Allcott and Gentzkow 2017; Bovet and Makse 2019). Early papers also discuss the subject of what determinants help to accurately identify fabricated news storiespredominantly based on US-related political topics. Several experimental studies found that the propensity to engage in analytical reasoning and actively open-minded thinking helps to distinguish between legitimate and false news stories (Bronstein et al. 2019; Pennycook and Rand 2019; Ross et al. 2019). In addition, Pennycook and Rand 2020 argue that overclaiming one's own level of knowledge is associated with judging false news stories as accurate.

In early 2020, the SARS-CoV-2 virus began to spread and caused a worldwide pandemic. The WHO (2020) labeled the information pollution during this crisis as infodemic. Uncertainty and anxiety about the future fueled conspiracy theories, which on the one hand provided a simple solution to deal with a difficult period of time but on the other hand had serious adverse health effects. Doubts about scientific evidence, as well as mistrust of politicians and other authorities, led people to believe that, for example, social distancing would not be necessary, face masks did not help to reduce the spread of the virus, and vaccination of all people was strategically intended by Bill Gates. During the Covid-19 crisis, trust in facts and evidence seems to play a cruical role to reduce transaction costs, which in turn helps to generate actions to combat the pandemic (Grüner and Krüger 2020). Taking into account the many warnings and information campaigns by the WHO and numerous scientists, Pennycook et al. (2020) argue that Covid-19 is a scientific issue. In their multi-country comparison (analyzing Ireland, Mexico, Spain, UK, and USA), Roozenbeek et al. (2020) identify trust in science and higher numeracy skills as protective factors against falling for false news stories. Moreover, they find evidence for a monological belief system: belief in one false news story is correlated with the belief in others. The latter has also been found by Georgiou et al. (2020) and Miller (2020) within the context of Covid-19.

This paper adds value to the literature of who is good at identifying false news stories / falling for false news information by systematically comparing three contexts: climate change, Covid-19, and artificial intelligence. While this study was carried out (December 2020), these contexts differed with respect to the frequency of media coverage, population activity in the form of demonstrations, daily deaths, and scientific knowledge. Covid-19 and climate change constitute scientific issues: in both contexts, scientists communicate facts and frequently provide behavioral recommendations. Almost all scientists agree that humans are causing global warming, which has multiple consequences, such as droughts, species extinction, and forest dieback (Maertens et al. 2020). In Germany, politicians announced plans to ban combustion engine cars. Fridays for future initiatives are widespread but thwarted by the Covid-19 
pandemic. Media coverage in Germany was by far dominated by the Covid-19 pandemic while the study was carried out. After the Northern Hemisphere has entered winter, the reported number of COVID-19 cases and deaths per day increased significantly. Political measures, such as social distancing and mandatory face-mask rules, were subject to (in part) controversial public discussions and demonstrations. It should also be mentioned that in Germany no vaccine was approved (but there were some promising candidates) when the study was underway. Artificial intelligence seems to be subordinate to the other contexts in terms of urgency and media coverage. While the public discourse on Covid-19 and climate change is more or less about avoiding harm, people in Germany also see some potential in artificial intelligence. In a nationwide survey conducted by the statistics portal Statista in September 2020,65\% of the individuals stated that artificial intelligence will lead to job losses. However, $45 \%$ of the individuals stated that artificial intelligence helps to avoid mistakes (Statista 2020).

Against this background, this paper tackles three questions:

(1) What determinants can explain the susceptibility to misinformation in the respective contexts?

(2) Can we observe monological belief systems in the respective contexts?

(3) Do individuals who are more susceptible to misinformation behave differently in their intention to vote and willingness to demonstrate?

The overall design of this study is most related to Roozenbeek et al. (2020): subjects were asked to rate the reliability of a couple of statements for each context. People are considered to be more susceptible to misinformation if they evaluate false news items as more reliable than other people do.

\section{Study design}

\subsection{Variable of interest}

The variable of interest is the extent to which subjects are susceptible to misinformation. For this purpose, subjects had to rate the reliability of short news items on a 7-point scale, ranging from very unreliable $(=1)$ to very reliable (7). Within all three contexts (climate change, Covid-19, and artificial intelligence) they were shown a total of 11 news items. Seven of them contain false news information (i.e., misinformation) and the other four are factual information. The latter was included to prevent the participants from seeing a pattern in the study that the subjects do not see a pattern in the study and, therefore, to blind the research objective. ${ }^{1}$ This paper deals only with the evaluation of false news information: The less reliable subjects rate these items, the less susceptible they are to misinformation.

\footnotetext{
${ }^{1}$ As ex-ante planned, the factual news items were not subject to any analysis.
} 
For example, within the context of climate change subjects were told: "There is no consensus in science about the causes of climate change." This statement is not true because the vast majority of scientists agree that global warming is man-made. Another fabricated news story is "Microsoft co-founder Bill Gates urges mandatory vaccination of all people." This is one example of the many wrong stories about Bill Gates that went viral during the Covid-19 pandemic/infodemic. A third example is the following one: "In Germany, artificial intelligence already makes diagnoses in medicine and independently takes decisions that affect people." This might be the case in the future but not nowadays. Currently, artificial intelligence does not make decisions in medicine on its own.

\subsection{Determinants}

Subjective Knowledge. It captures what individuals think they know about a topic. As opposed to their actual knowledge (objective knowledge), subjective knowledge is about their confidence (e.g. overconfidence; Ortoleva and Snowberg 2015). To measure subjective knowledge, we use the 5-item scale developed by Flynn and Goldsmith (1999). The agreement to several statements such as "I know pretty much about ..." was measured on a 7-point Likert scale ( 1 =strongly disagree, .., $7=$ strongly agree) for all three contexts (climate change / Covid-19 / artificial intelligence).

Information avoidance. Standard economics predicts that people incorporate all available information into their decision calculus. Since rational agents process information perfectly, having more information leads to better decisions in expectation. In reality, however, there are many situations in which people consciously forego information even when it is free (Golman et al. 2017). These include not only strategic reasons, but also the anticipation of negative news (e.g. diagnosis of a medical test). We use Howell and Sheppard's 8item scale to measure information avoidance. For example, the subjects are asked to indicate to what extent they agree with the statement "When it comes to (climate change / Covid-19 / artificial intelligence), sometimes ignorance is bliss." on a 7-point Likert scale ( $1=$ strongly disagree, .., $7=$ strongly agree).

Risk perception. It is about the evaluation of hazardous activities and technologies (Slovic 1987). As a result of experiences and individual attitudes, risks are perceived differently from person to person. Risk perception is measured on a 4-item scale. Subjects are asked, for example: "(Climate change / Covid-19 / Artificial intelligence) represents an issue where I am personally worried.” using a 7-point-scale. ${ }^{2}$

Willingness to think deliberately. According to the dual-process theory, the functioning of the human brain can be hypothetically divided into System 1 and System 2 (Stanovich and West 2000; Kahneman 2003).

\footnotetext{
${ }^{2}$ Since this scale was not tested before, we calculated alpha coefficients. It indicates acceptable internal consistency for the three contexts in our analysis (risk perception climate change: 0.8689, risk perception Covid-19: 0.7569, and risk perception artificial intelligence: 0.6848).
} 
System 1 is the intuitive/emotional system and System 2 is the reflective/analytical system. The cognitive reflection test (CRT; originally introduced by Frederick 2005) aims at measuring whether people are more intuitive or reflective thinkers. The questions of the test are structured in a manner that a quick (i.e., intuitive) answer is often wrong and deliberate thinking leads to the identification of the correct answer. High test scores are associated with reflective thinking, whereas lower scores are associated with more intuitive thinking. Our CRT test consists of the 3 items from Pennycook et al. 2020 (a re-worded version of Frederick 2005) and 3 items from a non-numeric CRT (Thomson and Oppenheimer 2016). Let us look at a sample question from our CRT test: "If you're running a race and you pass the person in second place, what place are you in?" An intuitive (but incorrect) answer is "first"; the correct answer is "second."

Actively open-minded thinking. It takes time and effort to process new information. Human behavior often exhibits some path dependency: according to the confirmation bias, information is selected and interpreted to be consistent with one's own expectations and beliefs (Lord et al. 1979). Actively open-minded thinking (AOT) is about the extent to which people consider evidence to adjust their beliefs and actively seek for alternative explanations. To measure AOT, we use the 7-item scale of Haran et al. (2013). Here, individuals indicate their agreement on a 7-point Likert scale (1=completely disagree to $7=$ completely agree) to statements such as "People should take into consideration evidence that goes against their beliefs."

Belief in conspiracy theories. The Macmillan Online dictionary (2020) defines a conspiracy theory as "the idea that a group of people secretly worked together to cause a particular event." Beginning with Popper (1945), the term has a negative connotation. Bruder et al. (2013) argue that conspiracy theories are meaningful in explaining political events and societal phenomena. We use the 5-item scale of Bruder et al. (2013) to measure belief in conspiracy theories. In this scale, people are asked to indicate how likely they think various events are on a scale from 0 (0\% - certainly not) to 10 (100\% - certain). One sample item is: "I think that many very important things happen in the world, which the public is never informed about."

\section{Statistical numeracy and risk literacy.}

People are exposed to a lot of quantitative information in everyday life. However, communicating quantitative information about benefits and risks of something is only meaningful if people can process it (Gigerenzer et al. 2005). It is therefore relevant whether people are able to process basic mathematical concepts. To elicit individual's statistical numeracy and risk literacy, we use the 8 items of the following tests: the 4-item Berlin Numeracy Test (Cokely et al. 2012), the 3-item Schwartz test (Schwartz et al. 1997), and 1 modified item from Wright et al. (2009). For example, subjects were asked the following question: "Out of 1,000 people in a small town 500 are members of a choir. Out of these 500 members in the choir 100 are men. Out of the 500 inhabitants that are not in the choir 300 are men. What is the probability that 
a randomly drawn man is a member of the choir? Please indicate the probability in percent." (correct answer is 25$)$.

Trust. In contrast to a world of rational utility maximizing agents, trust plays an important role in social and economic transactions (Fehr 2010). Trust helps to establish friendships and relationships and reduces transaction costs (e.g. monitoring) within companies and organizations (Frank 1988; Bromiley and Harris 2006). To elicit individual trust preferences, we ask individuals how much they trust in democracy, science, mass media, and social networks using a 7-point Likert scale, ranging from cannot be trusted at all $(=1)$ to can be trusted a lot $(=7)$.

Political attitude ("Political orientation: right"). The general political attitude reflects, at least in part, the individuals' perspective toward political measures. In Germany, for example, the right-wing populist political party AfD (“Alternative for Germany”) stands for criticism of measures (i.e., mistrust) taken by the German government. Individuals were asked to state their political attitude on the following scale: "In politics people often talk about "left" and "right" to distinguish different attitudes. If you think about your own political views: Where would you place them? Please answer using the following scale." (0 “entirely left" to 10 "entirely right").

Other variables. For further analysis, we asked the subjects about their willingness to vote in the next federal election $(1=\mathrm{No}, \ldots$, Yes $=5)$ and whether subjects ever have joined demonstration addressing climate change, Covid-19, or artificial intelligence $(0=$ Never done and no option, $1=$ Either done or people can imagine to do so). We also collected data on life satisfaction $(0=$ completely dissatisfied, $\ldots, 10=$ completely satisfied), age, education ( $1=$ no degree, .., $7=\mathrm{PhD})$, and gender $(1=$ female, $2=$ male, $3=$ other $)$ as controls, which will be only addressed if there are interesting findings in an exploratory analysis.

\section{Expected behavioral associations}

In the following, we present expected associations for the research questions described in the introduction.

a) What determinants can explain the susceptibility to misinformation in the respective contexts? (cf., Table 1)

We expect that subjective knowledge and susceptibility to misinformation are negatively correlated in all contexts: the more knowledgeable individuals feel, the more likely they are to identify fabricated news. There could be context differences for information avoidance. People might avoid information related to the contexts of climate change and Covid-19 since both are about negative consequences. However, facts about climate change are relatively robust--ignoring information in part does not necessarily lead to a loss of knowledge. During the Covid-19 crisis, people were frequently exposed to new information. However, news coverage was so extensive and repetitive (while this study was being carried out), which made it hard 
to run out of information on the topic. Thus, we do not expect information avoidance to be highly relevant in either context. In contrast, coverage of Artificial intelligence was relatively low: information avoidance may lead to being less well informed and, in turn, more susceptible to misinformation. It seems plausible to assume that there is a negative association between risk perception and susceptibility to misinformation. For example, if people do not consider Covid-19 to be a problem, then they might regard policy measures as a waste of resources and an inadequate way of restricting civil liberties. Following the results of several studies in the realm of false news stories, we assume that individuals' willingness to think deliberately and actively open-minded thinking protect against falling for misinformation. We expect that belief in conspiracy theories can predict falling for misinformation independently of the decision context. In contrast, statistical numeracy and risk literacy could help to better deal with numbers in general and probabilities in particular, both of which make it easier to interpret new quantitative information. Trust in

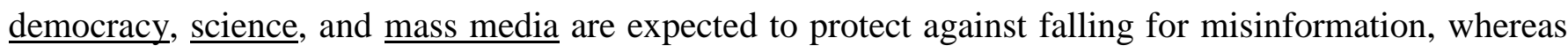
trust in social networks could be opposite. People are prone to be caught in a filter bubble in social networks. Moreover, we assume that politically-right-oriented people are more likely to systematically believe in misinformation.

Table 1: Ex-ante expected relationship between susceptibility to misinformation and determinants ${ }^{(1)}$

\begin{tabular}{|c|c|c|c|c|}
\hline Theoretical construct / variable & Climate change & Covid-19 & $\begin{array}{c}\text { Artificial } \\
\text { intelligence }\end{array}$ & $\begin{array}{c}\text { Expected context } \\
\text { differences }\end{array}$ \\
\hline Subjective knowledge & - & - & - & No \\
\hline Information avoidance & $=$ & $=$ & + & Yes \\
\hline Risk perception & - & - & - & No \\
\hline Willingness to think deliberately & - & - & - & No \\
\hline Actively open-minded thinking & - & - & - & No \\
\hline Belief in conspiracy theories & + & + & + & No \\
\hline Statistical numeracy and risk literacy & - & - & - & No \\
\hline Trust democracy & - & - & $=$ & Yes \\
\hline Trust science & - & - & $=$ & Yes \\
\hline Trust mass media & - & - & $=$ & Yes \\
\hline Trust social networks & + & + & $=$ & Yes \\
\hline Political orientation: right & + & + & $=$ & Yes \\
\hline
\end{tabular}

(1) Three symbols are used to describe our expectations between susceptibility to misinformation and the respective determinants: + (positive association), (negative association), and $=$ (no association)

b) Can we observe monological belief systems in the respective contexts?

There is some evidence for a monological belief system for Covid-19-related false information in the literature. We expect to see similar things in our other two contexts.

c) Do individuals who are more susceptible to misinformation behave differently in their intention to vote and willingness to demonstrate? 
We guess that people who are prone to misinformation are less likely to vote. However, it is ex-ante not easy to form expectations about the correlation between activity in demonstrations and falling for misinformation.

\section{Sampling procedure and Analytical approach}

\subsection{Sampling procedure}

The survey was conducted web-based between 2.12.2020-8.12.2020 using the online access panel of the Respondi AG. Subjects were paid between $€ 1.00$ and $€ 1.25$ for attending the 20-25 minute survey. The study was approved by the Commission on Ethical Questions in Science of the Martin Luther University Halle-Wittenberg.

\subsection{Analytical approach}

\section{(1) Determinants to explain the susceptibility to misinformation}

Our primary research goal was to find out who is susceptible to misinformation. The subjects were asked to rate the reliability of several statements on a 7-point Likert scale, ranging from very unreliable (1) to very reliable (7). Within each of the three contexts climate change, Covid-19, and artificial intelligence, we presented subjects with 7 statements which contain misinformation. To measure susceptibility to misinformation for each context, we calculated an index by aggregating the scores of the answers to the respective items. The higher the score, the more prone the people are to misinformation. Since the dependent variables can take values from 7 to 49, we run ordinary least squares (OLS) linear regressions.

In the regression analysis to explain the individuals' susceptibility to misinformation, we use scales with different numbers of items. To make it comparable, we provide standardized beta coefficients. A BreuschPagan test rejects the null hypothesis of homoskedasticity in the three ordinary least squares (OLS) linear regressions to explain the susceptibility to misinformation about climate change ( $\mathrm{p}$-value $=0.0004)$, Covid19 ( $\mathrm{p}$-value $<0.0001$ ), and artificial intelligence ( $\mathrm{p}$-value=0.0027). Therefore, heteroscedasticity consistent standard errors are used in the linear regression model.

As Altman and Bland (1995) point out "absence of evidence is not evidence of absence." For example, it would be wrong to argue that p-values of 0.1 are evidence that there is nothing. In contrast, we cannot say much about such a finding within our study.

\section{(2) Can we observe monological belief systems in the respective contexts?}

Within each context, we calculate zero-order correlations (i.e., Pearson correlation coefficients) between the statements that contain misinformation. To deal with multiple comparisons, we provide Bonferroni adjusted p-values. We also show 95\% confidence intervals for Pearson's product-moment correlation. In 
addition, we conduct a between context analysis: the correlations of the aggregated susceptibility to misinformation between the three contexts are depicted. Here, we also correct for multiple comparisons (Bonferroni) and display confidence intervals.

\section{(3) Do individuals who are more susceptible to false news information behave differently in their} intention to vote and activity in demonstrations?

The zero-order correlations (Pearson correlation coefficients) between the susceptibility to misinformation and the individuals' willingness to vote are calculated for each context. P-values are Bonferroni corrected.

The correlation between the willingness to demonstrate (yes $=1$, no=0) and the susceptibility to misinformation within each context are calculated with the point biserial correlation coefficient (which is a true Pearson product-moment correlation). P-values are Bonferroni corrected.

\section{Description of the participants}

A total of 505 participants ( 252 women, $253 \mathrm{men}^{3}$ ) participated in the study (cf., Table 2). ${ }^{4}$ On average, they are 48.45 years old. Roughly $1 / 3$ of the participants (31.29\%) have a university entrance qualification (“Abitur") or higher. On a 10-point Likert scale ( $0=$ completely dissatisfied, $\ldots, 10=$ completely satisfied), participants indicated an average life satisfaction of 6.33 and an average political attitude of $4.76(0=$ entirely left, .., $10=$ entirely right).

Within this study, the contexts of climate change, Covid-19, and artificial intelligence are compared with each other. For this purpose, a number of variables were collected. The tendency to avoid information is most pronounced for the contexts of artificial intelligence and climate change; but relatively low for Covid19. On average, the participants indicate a high level of risk perception in the contexts Covid-19 and climate change. In contrast, artificial intelligence is not perceived as a major concern. Participants rate their subjective knowledge highest for Covid-19. The perceived knowledge is lower in the area of climate change and lowest in artificial intelligence. In addition, questions were asked about trust in various domains: trust in science and democracy is relatively high. Less people trust the mass media and trust in social networks is noticeably low.

\footnotetext{
${ }^{3}$ Only two subjected indicated themselves as "other." We dropped them to make the variable dichotomous, which simplifies the analysis (female $=1$, male $=2$ ).

${ }^{4}$ This section gives a brief overview of the participants in the study. Some further details are presented in Appendix 1.
} 
Table 2: Socio-demographic characteristics of the sample $(N=505)$

\begin{tabular}{|l|c|c|c|}
\hline Label & Mean & SD & Range of scale \\
\hline Age & 48.45 & 13.51 & $18-\ldots$ \\
\hline Education & 3.318 & 1.28 & $1-2$ \\
\hline Gender (male in \%) & 50.10 & - & $0-10$ \\
\hline Life satisfaction & 6.333 & 2.26 & $0-10$ \\
\hline Political orientation: right & 4.76 & 1.80 & $8-56$ \\
\hline Information avoidance & & 10.51 & $8-56$ \\
\hline Climate change & 26.02 & 11.00 & $8-56$ \\
\hline Covid-19 & 22.52 & 10.67 & $4-28$ \\
\hline Artificial Intelligence & 28.34 & & $4-28$ \\
\hline Risk perception & & 5.30 & $4-28$ \\
\hline Climate change & 20.21 & 4.93 & \\
\hline Covid-19 & 21.75 & 4.03 & $5-35$ \\
\hline Artificial Intelligence & 15.52 & & $5-35$ \\
\hline Subjective knowledge & & 5.31 & $5-35$ \\
\hline Climate change & 19.70 & 4.71 & $1-7$ \\
\hline Covid-19 & 22.68 & 5.63 & $1-7$ \\
\hline Artificial Intelligence & 17.84 & 1.63 & $1-7$ \\
\hline Trust democracy & 4.10 & 1.49 & $1-7$ \\
\hline Trust mass media & 3.73 & 1.39 & \\
\hline Trust science & 4.74 & 1.27 & \\
\hline Trust social networks & 2.59 & & \\
\hline
\end{tabular}

\section{Results}

The index "susceptibility to misinformation" can take values from 7 to 49 , with a higher value indicating more susceptibility to false information. On average, participants were slightly more susceptible to misinformation in the fields of artificial intelligence $(\mathrm{M}=22.83, \mathrm{SD}=6.93)$ and climate change $(\mathrm{M}=22.28$, $\mathrm{SD}=8.52)$ than in Covid-19 $(\mathrm{M}=19.02, \mathrm{SD}=8.99)$. We now want to illustrate the index susceptibility to misinformation for each context with the help of a violin plot, which can broadly be considered as a combination of a box plot and a kernel density plot (cf., Figure 1). Moreover, it helps to illustrate the distribution of the data. The median is indicated in the respective violin plots by a white dot: it is 21 (climate change), 18 (Covid-19), and 23 (artificial intelligence). Moreover, information is provided about the interquartile range (IQR), a measure of variability, depicted as the bar in the center of the violin plot. It is the difference between the upper and lower quartiles (i.e., the middle 50\%). We get the following differences in the respective contexts: climate change $(27-16=11)$, Covid-19 $(25-12=13)$, and artificial intelligence (27-18=9). The lower adjacent values (first quartile $-1.5 \mathrm{IQR}$ ) and the upper adjacent values (third quartile $+1.5 \mathrm{IQR})$ are illustrated as lines stretched from the bar: climate change $(7 ; 43)$, Covid-19 $(7 ; 44)$, and artificial intelligence $(7 ; 40)$. 
Figure 1: Determinants to explain susceptibility to misinformation $(\mathrm{N}=505)$

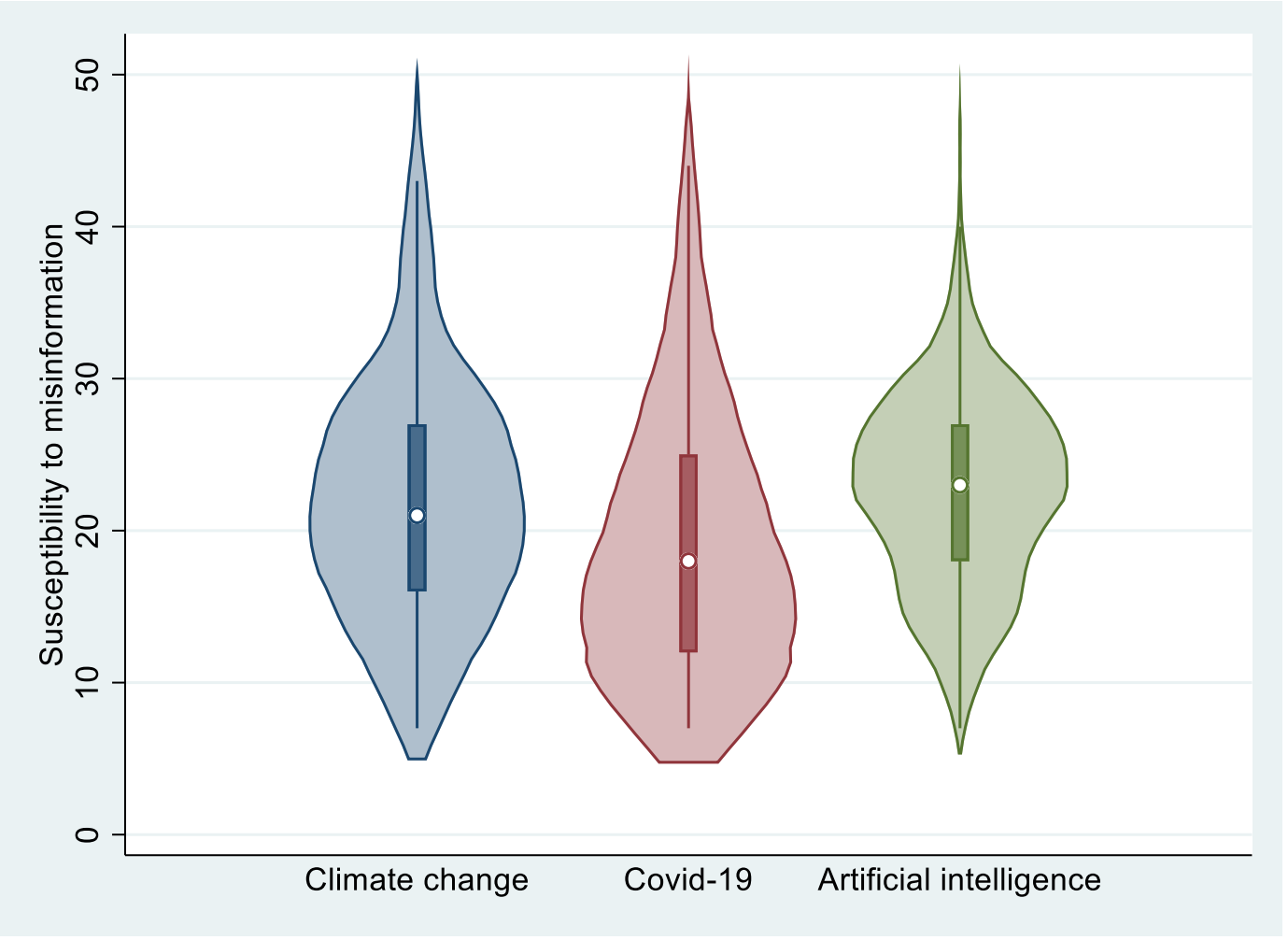

\subsection{Determinants to explain susceptibility to misinformation}

The respective econometric regressions to explain the association between susceptibility to misinformation and several determinants are shown in Table 3. The higher the susceptibility to misinformation, the worse the ability to identify false information. In other words, variables with negative signs may protect to fall for false news information.

Subjective knowledge does not seem to play a role in the contexts of climate change $(\mathrm{b}=-0.007$, $\mathrm{p}$ value $=0.855)$ and Covid-19 ( $b=0.002, p$-value=0.940). For artificial intelligence, we find to our surprise a positive association between subjective knowledge and falling for misinformation $(b=0.177, p-$ value $<0.001$ ). Maybe subjective knowledge could be biased because many people have an opinion about climate change and Covid-19 due to the abundance of information. Artificial intelligence is rarely mentioned in everyday life, but it is often part of science fiction: insofar as individuals mix up the source where information comes from, less reliable sources can become important (i.e., source confusion). Information avoidance appears to be negligible when it comes to explaining susceptibility to misinformation. In the panels I and II the effect sizes are practically zero and the p-values $>0.8$. The coefficient in the context of artificial intelligence is substantially larger $(b=0.072)$ but the relatively large p-value (0.141) does not allow for an interpretation within this study. As expected, risk perception and susceptibility to misinformation are substantively negatively related to both climate change $(b=-0.487, p-$ 
value $<0.001)$ and Covid-19 ( $b=-0.243$, p-value<0.001). However, there does not seem to be such an effect for artificial intelligence $(b=0.017, p$-value $=0.686)$. These findings may reflect, in part, structural differences across the contexts. The public discourse on climate change and Covid-19 was foremost about avoiding negative consequences (e.g. risks and hazards) from society. It was embedded in scientific evidence. In contrast, the field of artificial intelligence is not that familiar to people. Negative but also positive consequences can come along and it is hard to predict how things will develop in the future.

Subjects' willingness to think deliberately and actively open-minded thinking are to some extent negatively related to falling for misinformation. The standardized beta coefficients of actively open-minded thinking are a little bit larger than those for the willingness to think deliberately within the contexts climate change $(b=-0.083$, p-value=0.056; $b=-0.068, p$-value $=0.067)$ and Covid-19 $(b=-0.107, p$-value $=0.008 ; b=-0.060$ $\mathrm{p}=0.107)$. We refrain from interpreting the findings for artificial intelligence due to the high $\mathrm{p}$-values $(>0.2)$. These findings signal that the manner of thinking is more important for climate Chance and Covid-19 than for artificial intelligence. Belief in conspiracy theories seems to be an important determinant to explain the susceptibility to misinformation but only for Covid-19 ( $b=0.297$, $p$-value $<0.001)$ and artificial intelligence $(b=0.333$, $p$-value $<0.001)$. The coefficient of climate change is positive but the $p$-value is too high to make a statement about the association $(\mathrm{p}$-value $=0.164)$. Conspiracy theories might play a more important role in contexts where things are uncertain. In December 2020, only expectations about the future course of Covid-19 could be made, but with a great deal of uncertainty for people, which fuels conspiracy theories. With artificial intelligence, future developments are also difficult to predict. Somewhat surprisingly, we cannot argue that statistical numeracy and risk literacy protects against misinformation. Our analysis shows that the p-values are too large (climate change: 0.341; Covid-19: 0.201, and artificial intelligence: 0.111). Being good at statistics seems to be not enough to protect against false news information. People often do not have to interpret probabilities and other numbers themselves, but are given interpretations by institutions and politicians. Therefore, trust might be a more important protective factor against falling for misinformation.

Let us take a look at trust in democracy, science, and mass media. These variables do not seem to protect much against the susceptibility to misinformation in the field of artificial intelligence ( $p$-values $>0.2$ ). Trust in democracy $(b=-0.091, p$-value $=0.057)$ and trust in mass media $(b=-0.119, p$-value $=0.015)$ are negatively associated with falling for misinformation in the realm of climate change. Trust in science $(b=-0.160, p-$ value $=0.001$ ) seems to be an important driver against Covid-19-related misinformation. A possible explanation for this is that the content of climate change-related news is quite robust in time (i.e., knowledge is to some extent given). In contrast, the Covid-19 pandemic is associated with developing vaccines and other forms to protect against the virus, which was often suggested by scientists. As expected, trust in social 
networks is positively associated with falling for misinformation over all contexts ( $b>0.1, p$-values $\leq 0.010)$. On social networks, literally everyone can write and share what they want. There is a lack of verification of the posts (i.e., no gatekeeper). The more people are politically right-orientated, the more they fall for climate change-related news $(b=0.075$, $p$-value $=0.031)$. Also in line with our expectations is the effect in the context of artificial intelligence: it is largely a non-political topic and, therefore, politics seems to play a minor role ( $\mathrm{p}$-value $=0.467$ ). The association between political orientation and falling for misinformation is somewhat surprising in the context of Covid-19 $(b=0.034$, $p$-value $=0.259)$. However, if we run an alternative regression without controlling for the four trust variables, the association of political orientation becomes considerably larger $(b=0.056$; $p$-value $=0.098)$, indicating that there is some correlation between trust and political orientation.

\section{Exploratory analysis}

Education in terms of formal degrees does not seem to be a protective factor against susceptibility to misinformation. The standardized beta coefficients are either (close to) zero ( -0.003 , panel II) or even positive (0.060, panel I; 0.079, panel III). However, the p-values are quite large $(>0.1)$, therefore, the association between education and falling for misinformation is left open for future research. Surprisingly, there seems to be a gender effect: men seem to be more prone to misinformation in the contexts of climate change $(b=0.084$, $p$-value $=0.021)$ and Covid-19 $(b=0.096$, $p$-value=0.005). Further research must show whether is an artifact or the outcome of possible gender differences in search and processing information. 
Table 3: Determinants to explain susceptibility to misinformation $(\mathrm{N}=505)$

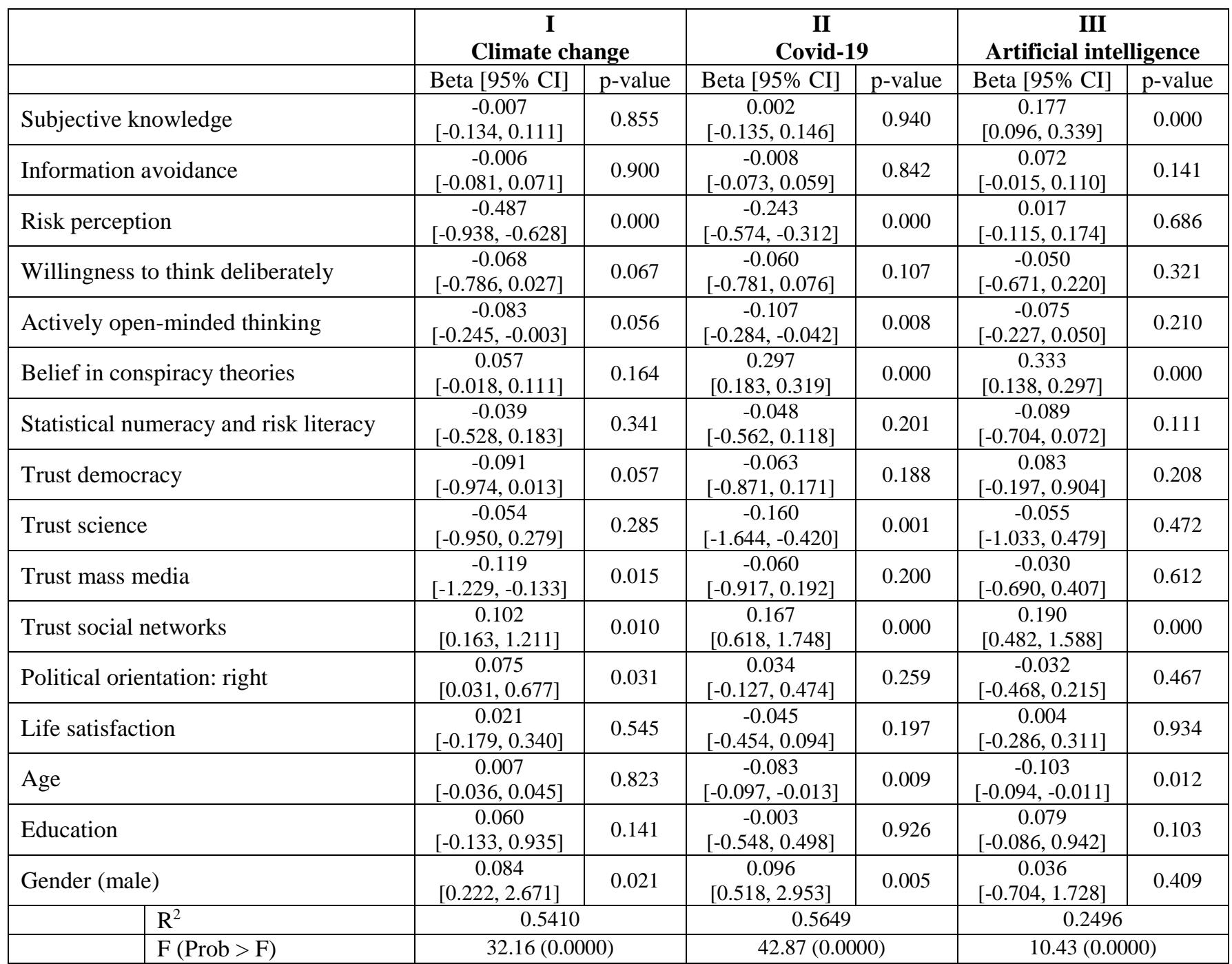

\subsection{Monological belief system}

The magnitude of the correlation between the statements in the respective contexts can be described as moderate. In other words, there is some evidence for monological belief systems (i.e., being susceptible to one false news statement has predictive power to the other false news statements), which seems, however, more pronounced for climate change and Covid-19 than for artificial intelligence (cf., Tables 4-6). In the following, we try to make sense of these findings. Individuals may differ in their ability to identify false news. As a consequence, they do not only fall for one but for a couple of false news statements (i.e., general susceptibility to misinformation). The general susceptibility to misinformation argument is supported by the considerable correlation of the context-to-context susceptibility to misinformation (cf., Table 7). However, this explanation does not account for context-specific differences.

Context-specific differences could be explained by the concept of narratives (Shiller 2019, Gruener 2020). In contrast to rational choice, individuals often do not think in terms of equations but in stories. Let us 
presume, for illustrative purposes, that Covid-19 is not perceived to be a problem. As a consequence, policy measures to mitigate Covid-19 may be viewed critically, including the use of masks and social distancing. Similar to a spider's web, many aspects are interconnected with each other. In other words, stories are bigger than simple statements. Therefore, it is no surprise that the susceptibility to misinformation in one statement is considerably related to the susceptibility to misinformation of other statements. It should be noted that confirmation bias has a certain relevance here, i.e. trust in statements as long as it is in line with prior beliefs. Artificial intelligence receives relatively little public attention (compared to climate change and Covid-19). It is conceivable that many people have not formed a clear opinion on the subject (no prior beliefs), which may cause context differences. In addition, context differences may arise because artificial intelligence is structurally different: benefits and drawbacks are possible; whereas climate change and Covid-19 are about avoiding harm.

Table 4: Correlation between statements - Climate Change ${ }^{(a, b)}$

\begin{tabular}{|c|c|c|c|c|c|c|c|}
\hline \#Statement & V17 & V18 & V19 & $\mathrm{V} 21$ & V22 & V24 & $\mathrm{V} 25$ \\
\hline V17- No evidence & - & & & & & & \\
\hline V18- Unclear causes & $\begin{array}{c}0.4772 \\
{[0.407,0.542]} \\
\end{array}$ & - & & & & & \\
\hline V19- Not humans & $\begin{array}{c}0.4366 \\
{[0.363,0.505]}\end{array}$ & $\begin{array}{c}0.5185 \\
{[0.452,0.580]}\end{array}$ & - & & & & \\
\hline V21- No influence & $\begin{array}{c}0.4398 \\
{[0.367,0.508]}\end{array}$ & $\begin{array}{c}0.5036 \\
{[0.436,0.566]}\end{array}$ & $\begin{array}{c}0.5839 \\
{[0.523,0.639]}\end{array}$ & - & & & \\
\hline V22- Invalid models & $\begin{array}{c}0.4192 \\
{[0.345,0.489]} \\
\end{array}$ & $\begin{array}{c}0.4818 \\
{[0.412,0.546]} \\
\end{array}$ & $\begin{array}{c}0.4426 \\
{[0.370,0.510]} \\
\end{array}$ & $\begin{array}{c}0.4503 \\
{[0.378,0.517]} \\
\end{array}$ & - & & \\
\hline V24- Sun & $\begin{array}{c}0.4194 \\
{[0.345,0.489]} \\
\end{array}$ & $\begin{array}{c}0.4016 \\
{[0.326,0.472]} \\
\end{array}$ & $\begin{array}{c}0.3945 \\
{[0.318,0.466]} \\
\end{array}$ & $\begin{array}{c}0.4372 \\
{[0.364,0.505]} \\
\end{array}$ & $\begin{array}{c}0.3634 \\
{[0.285,0.437]} \\
\end{array}$ & - & \\
\hline V25- Government & $\begin{array}{c}0.4949 \\
{[0.426,0.558]}\end{array}$ & $\begin{array}{c}0.4857 \\
{[0.416,0.550]}\end{array}$ & $\begin{array}{c}0.4462 \\
{[0.373,0.513]}\end{array}$ & $\begin{array}{c}0.5205 \\
{[0.454,0.581]}\end{array}$ & $\begin{array}{c}0.4324 \\
{[0.359,0.501]}\end{array}$ & $\begin{array}{c}0.5181 \\
{[0.359,0.501]}\end{array}$ & - \\
\hline
\end{tabular}

(a) $95 \% \mathrm{CI}$ in brackets.

(b) All Bonferroni adjusted p-values are $<0.0001$.

Table 5: Correlation between statements-Covid-19 ${ }^{(a, b)}$

\begin{tabular}{|c|c|c|c|c|c|c|c|}
\hline \#Statement & V28 & V29 & V30 & V32 & V33 & V35 & V36 \\
\hline V28- Like the flu & - & & & & & & \\
\hline V29- Bill Gates & $\begin{array}{c}0.3846 \\
{[0.308,0.457]}\end{array}$ & - & & & & & \\
\hline V30- 5G & $\begin{array}{c}0.3809 \\
{[0.304,0.45]} \\
\end{array}$ & $\begin{array}{c}0.4445 \\
{[0.372,0.512]} \\
\end{array}$ & - & & & & \\
\hline V32- Masks: damage & $\begin{array}{c}0.4706 \\
{[0.400,0.536]}\end{array}$ & $\begin{array}{c}0.4786 \\
{[0.408,0.543]}\end{array}$ & $\begin{array}{c}0.4411 \\
{[0.368,0.509]}\end{array}$ & - & & & \\
\hline V33- Warn-App & $\begin{array}{c}0.4117 \\
{[0.337,0.482]}\end{array}$ & $\begin{array}{c}0.4653 \\
{[0.394,0.531]}\end{array}$ & $\begin{array}{c}0.4029 \\
{[0.327,0.474]}\end{array}$ & $\begin{array}{c}0.5197 \\
{[0.453,0.581]}\end{array}$ & - & & \\
\hline V35- Masks: profit & $\begin{array}{c}0.3144 \\
{[0.234,0.391]}\end{array}$ & $\begin{array}{c}0.3786 \\
{[0.301,0.451]}\end{array}$ & $\begin{array}{c}0.3273 \\
{[0.247,0.403]}\end{array}$ & $\begin{array}{c}0.4319 \\
{[0.358,0.500]}\end{array}$ & $\begin{array}{c}0.3970 \\
{[0.321,0.468]}\end{array}$ & - & \\
\hline V36- Cause of death & $\begin{array}{c}0.4637 \\
{[0.392,0.530]}\end{array}$ & $\begin{array}{c}0.5158 \\
{[0.449,0.577]}\end{array}$ & $\begin{array}{c}0.4786 \\
{[0.408,0.543]}\end{array}$ & $\begin{array}{c}0.5647 \\
{[0.502,0.621]}\end{array}$ & $\begin{array}{c}0.5202 \\
{[0.453,0.581]}\end{array}$ & $\begin{array}{c}0.5046 \\
{[0.437,0.567]}\end{array}$ & - \\
\hline
\end{tabular}

(a) $95 \% \mathrm{CI}$ in brackets.

(b) All Bonferroni adjusted p-values are $<0.0001$. 
Table 6: Correlation between statements-Artificial intelligence ${ }^{(a, b)}$

\begin{tabular}{|c|c|c|c|c|c|c|c|}
\hline \#Statement & V39 & V40 & V41 & V43 & V44 & V46 & V47 \\
\hline V39- Medicine & - & & & & & & \\
\hline V40- Staff decision & $\begin{array}{c}0.5550 \\
{[0.491,0.613]}\end{array}$ & - & & & & & \\
\hline V41- Cheating school & $\begin{array}{c}0.3356 \\
{[0.256,0.411]}\end{array}$ & $\begin{array}{c}0.3519 \\
{[0.273,0.426]}\end{array}$ & - & & & & \\
\hline V43- Robots & $\begin{array}{c}0.1756 \\
{[0.090,0.259]} \\
\end{array}$ & $\begin{array}{c}0.1747 \\
{[0.089,0.258]}\end{array}$ & $\begin{array}{c}0.2856 \\
{[0.203,0.364]} \\
\end{array}$ & - & & & \\
\hline V44- Voice assistant & $\begin{array}{c}0.4330 \\
{[0.359,0.501]}\end{array}$ & $\begin{array}{c}0.3130 \\
{[0.232,0.390]}\end{array}$ & $\begin{array}{c}0.5179 \\
{[0.451,0.579]}\end{array}$ & $\begin{array}{c}0.2060 \\
{[0.121,0.288]}\end{array}$ & - & & \\
\hline V46- Singers & $\begin{array}{c}0.2896 \\
{[0.208,0.368]}\end{array}$ & $\begin{array}{c}0.3103 \\
{[0.229,0.387]}\end{array}$ & $\begin{array}{c}0.4392 \\
{[0.366,0.507]}\end{array}$ & $\begin{array}{c}0.2532 \\
{[0.170,0.333]}\end{array}$ & $\begin{array}{c}0.4312 \\
{[0.357,0.500]}\end{array}$ & - & \\
\hline V47- Kasparov & $\begin{array}{c}0.2916 \\
{[0.210,0.369]}\end{array}$ & $\begin{array}{c}0.2136 \\
{[0.129,0.295]}\end{array}$ & $\begin{array}{c}0.4153 \\
{[0.340,0.485]}\end{array}$ & $\begin{array}{c}0.1750 \\
{[0.089,0.258]}\end{array}$ & $\begin{array}{c}0.5287 \\
{[0.463,0.589]}\end{array}$ & $\begin{array}{c}0.3796 \\
{[0.302,0.452]}\end{array}$ & - \\
\hline
\end{tabular}

(a) $95 \% \mathrm{CI}$ in brackets.

(b) Four Bonferroni adjusted p-values slightly deviate from < 0.0001: V43 x V39 (0.0015), V43 x V40 (0.0017), V44 x V43 (0.0001), and V47 x V43 (0.0016).

Table 7: Correlation between contexts ${ }^{(a, b)}$

\begin{tabular}{|l|c|c|c|}
\hline & \multicolumn{3}{|c|}{ Susceptibility to Misinformation } \\
\hline & $\begin{array}{c}\text { Climate } \\
\text { Change }\end{array}$ & Covid-19 & $\begin{array}{c}\text { Artificial } \\
\text { Intelligence }\end{array}$ \\
\hline Climate Change & - & & \\
\hline Covid-19 & $\begin{array}{c}0.5811 \\
{[0.520,0.636]}\end{array}$ & - & \\
\hline Artificial Intelligence & $\begin{array}{c}0.3412 \\
{[0.262,0.416]}\end{array}$ & $\begin{array}{c}0.5295 \\
{[0.464,0.589]}\end{array}$ & - \\
\hline
\end{tabular}

(a) $95 \% \mathrm{CI}$ in brackets.

(b) All Bonferroni adjusted p-values are $<0.0001$.

\subsection{Implications of the susceptibility to misinformation}

\section{Intention to vote}

There is a small, negative association between being susceptibility to misinformation and the willingness to vote over all contexts: climate change ( $\mathrm{r}=-0.1661, \mathrm{p}$-value $=0.0011,95 \% \mathrm{CI}=-0.250$ to -0.080$)$, Covid-19 $(\mathrm{r}=-0.2638$, $\mathrm{p}$-value $<0.0001,95 \% \mathrm{CI}=-0.343$ to -0.181$)$, and artificial intelligence $(\mathrm{r}=-0.1658, \mathrm{p}-$ value $=0.0011,95 \% \mathrm{CI}=-0.249$ to -0.080$)$. This finding has economic consequences: people who fall for false news stories seem to be less likely to spread biased beliefs via voting.

\section{Activity in demonstrations}

There is a negative association between being prone to climate change-related misinformation and the tendency to attend demonstrations on climate change $(\mathrm{r}=-0.2878, \mathrm{t}=-6.7392$, $\mathrm{p}$-value $<0.0001)$. A positive sign can be found in the contexts of Covid-19 ( $\mathrm{r}=0.2615, \mathrm{t}=6.0766$, $\mathrm{p}$-value $<0.0001)$ and artificial intelligence $(\mathrm{r}=0.1311, \mathrm{t}=2.9657$, $\mathrm{p}$-value $=0.0096)$. In other words, people who believe in misinformation stay at home when it is about climate change and are more active when it comes to Covid- 19 . 


\section{Discussion and Conclusion}

Competition of ideas (e.g. about policies or products) constitutes a fundament of democratic processes. To adequately evaluate courses of action, it is critical that people do not fall for misinformation. For example, if people are susceptible to corona-related misinformation, individuals may refuse wearing masks or social distancing. There are immediate health implications for people, but also consequences to the economy if lockdowns are necessary due to adverse consequences as a result of not following given rules. Recent studies have shown and it was replicated by our study, that there is a monological belief system, i.e., people who fall for one false news item are more likely to fall to other false news stories, too. However, people may also neglect and deliberately misinterpret information (Golman et al 2017). Therefore, it is important to know the determinants under which circumstances people are prone to misinformation. Against this background, we carried out a study to analyze the susceptibility to misinformation in the three contexts climate change, Covid-19, and artificial intelligence. While this study had been carried out, Covid-19 was a big topic in the media, climate change was also present, but artificial intelligence was largely neglected in the news coverage. Within all three contexts, we find that trust in social networks is positively associated with susceptibility to misinformation. However, there are also a couple of protective factors: individuals are less likely to be susceptible to misinformation in the contexts of climate change and Covid-19 if they have a higher risk perception, tend to take a second look at a problem (i.e., willingness to think deliberately), update their prior beliefs to new evidence (actively open-minded thinking), and trust in science and mass media. Within the context of artificial intelligence, being less prone to conspiracy theories in general and lower subjective knowledge helps not to be susceptible to misinformation.

Our study has some practical implications related to the finding that people who trust in social networks are more prone to misinformation in all three contexts. It seems to be important to raise the problem awareness of misinformation in social networks. Maybe more fact-checking initiatives could be established. Moreover, the role of gatekeepers on the Internet can be improved. There is another implication of our study related to context-specific differences in the susceptibility to misinformation. Context matters when it comes to misinformation. In our case, we had climate change and Covid-19, both of which are about avoiding harm to the society, and artificial intelligence, which merely lacks prior beliefs and can be both associated with positive and negative consequences. Further research needs to further tackle such differences not only using panel surveys (such as our study) but also representative investigations. There are at least two further open questions as a consequence of our study: (1) When does education help to protect against misinformation? (2) Are there gender differences in the search and processing of information? 


\section{References}

Allcott, H., Gentzkow, M. (2017): Social Media and Fake News in the 2016 Election. Journal of Economic Perspectives 31(2): 211-236.

Altman, D.G., Bland, J.M. (1995): Absence of evidence is not evidence of absence. British Medical Journal 311(7003): 485. doi: 10.1136/bmj.311.7003.485.

Bovet, A., Makse, H.A. (2019): Influence of fake news in Twitter during the 2016 US presidential election. Nature Communications 10(7). doi: 10.1038/s41467-018-07761-2.

Bronstein, M.V., Pennycook, G., Bear, A., Rand, D.G., Cannon, T.D. (2019): Belief in Fake News is Associated with Delusionality, Dogmatism, Religious Fundamentalism, and Reduced Analytic Thinking. Journal of Applied Research in Memory and Cognition 8(1): 108-117.

Bromiley, P., Harris, J. (2006): Trust, transaction cost economics, and mechanisms. In: Handbook of Trust Research: Bachmann, R., Zaheer, A. (eds.): 124-143. Edward Elgar, Cheltenham.

Bruder, M., Haffke, P., Neave, N., Nouripanah, N., Imhoff, R. (2013): Measuring individual differences in generic beliefs in conspiracy theories across cultures: Conspiracy Mentality Questionnaire. Frontiers in Psychology 4(225). doi: 10.3389/fpsyg.2013.00225.

Cokely, E.T., Galesic, M., Schulz, E., Ghazal, S., Garcia-Retamero, R. (2012): Measuring risk literacy: the Berlin Numeracy Test. Judgment and Decision Making 7(1): 25-47.

Flynn, L.R., Goldsmith, R.E. (1999): A Short, Reliable Measure of Subjective Knowledge. Journal of Business Research 46(1): 57-66.

Fehr, E. (2010): On the economics and biology of trust. Journal of the European Economics Association, 7(2-3): 235266.

Frank, R. (1988): Passion within Reason: The Strategic Role of Emotions. Norton, New York.

Georgioua, N., Delfabbroa, P., Balzanb, R. (2020): COVID-19-related conspiracy beliefs and their relationship with perceived stress and pre-existing conspiracy beliefs. Personality and Individual Differences 166:110201. doi:10.1016/j.paid.2020.110201.

Gigerenzer, G., Hertwig, R., van den Broek, E., Fasolo, B., Katsikopoulos, K. (2005): A 30\% chance of rain tomorrow: How does the public understand probabilistic weather forecasts? Risk Analysis 25(3): 623-629.

Golman, R., Hagmann, D., Loewenstein, G. (2017): Information Avoidance. Journal of Economic Literature 55(1): 96-135.

Gruener, S. (2020): Identifying and debunking environmental-related false news stories-An experimental study. doi: $10.31235 /$ osf.io/zmx 5p

Grüner, S., Krüger, F. (2020): The intention to be vaccinated against COVID-19: stated preferences before vaccines were available. Applied Economics letters: https://doi.org/10.1080/13504851.2020.1854445.

Haran, U., Ritov, I., Mellers, B.A. (2013): The role of actively open-minded thinking in information acquisition, accuracy, and calibration. Judgment and Decision Making 8(3): 188-201.

Howell, J.L., Shepperd, J.A. (2016): Establishing an Information Avoidance Scale. Psychological Assessment 28(12): 1695-1708.

Kahneman, D (2003): A perspective on judgement and choice. American Psychologist 58(9): 697-720. 
Lord, C.G., Ross, L., Lepper, M.R. (1979): Biased assimilation and attitude polarization: The effects of prior theories on subsequently considered evidence. Journal of Personality and Social Psychology 37(11): 2098-2109.

Macmillan Online dictionary (2020): https://www.macmillandictionary.com/dictionary/british/conspiracy-theory (accessed 27 December 2020).

Maertens, R., Anseel, F., Van der Linden, S. (2020). Combatting climate change misinformation: Evidence for longevity of inoculation and consensus messaging effects. Journal of Environmental Psychology 70: 101455. doi: 10.1016/j.jenvp.2020.101455.

Miller, J.M. (2020): Do COVID-19 conspiracy theory beliefs form a monological belief system? Canadian Journal of Political Science. doi: 10.1017/S0008423920000517.

Ortoleva, P., Snowberg, E. (2015): Overconfidence in Political Behavior. American Economic Review 105(2): 504535.

Pennycook, G., Rand, D. (2019): Lazy, not biased: Susceptibility to partisan fake news is better explained by lack of reasoning than by motivated reasoning. Cognition 188: 39-50.

Pennycook, G., Rand, D.G. (2020): Who falls for fake news? The roles of bullshit receptivity, overclaiming, familiarity, and analytic thinking. Journal of Personality 88(2): 185-200.

Pennycook, G., McPhetres, J., Bago, B., Rand, D.G. (2020): Attitudes about COVID-19 in Canada, the U.K., and the U.S.A.: A novel test of political polarization and motivated reasoning: https://doi.org/10.31234/osf.io/zhjkp.

Popper, K.R. (1945): Die offene Gesellschaft und ihre Feinde [The Open Society and Its Enemies]. Teil 1: Der Zauber Platons [The Spell of Plato]. Routledge, London.

Roozenbeek, J., Schneider, C.R., Dryhurst, S., Kerr, J., Freeman, A.L.J., Recchia, G., van der Bles, A.M., van der Linden, S. (2020): Susceptibility to misinformation about COVID-19 around the world. Royal Society Open Science 7: 201199. http://dx.doi.org/10.1098/rsos.201199

Ross, R.M., Rand, D.G., Pennycook, G. (2019). Beyond "fake news": The role of analytic thinking in the detection of inaccuracy and partisan bias in news headlines. https://doi.org/10.31234/osf.io/cgsx6

Schwartz, L.M.L., Woloshin, S.S, Black, W.C.W., Welch, H.G.H. (1997): The role of numeracy in understanding the benefit of screening mammography. Annals of Internal Medicine 127(11): 966-972.

Shiller, R.J. (2019): Narrative Economics: How Stories Go Viral and Drive Major Economic Events. Princeton University Press, Princeton/Oxford.

Slovic, P. (1987): Perception of risk. Science 236(4799): 280-285.

Stanovich, K.E., West, RF. (2000): Individual difference in reasoning: implications for the rationality debate? Behavioral and Brain Sciences. 23(5): 645-726.

Statista (2020): https://de.statista.com/statistik/daten/studie/1176941/umfrage/vorstellungen-von-kuenstlicherintelligenz-am-arbeitsplatz-in-deutschland (accessed 25 December 2020).

Thomson, K.S., Oppenheimer, D.M. (2016): Investigating an alternate form of the cognitive reflection test. Judgment and Decision Making 11(1): 99-113.

World Health Organization (2020): Novel Coronavirus(2019-nCoV): Situation Report 13, 2 February: www.who.int/docs/default-source/coronaviruse/situation-reports/20200202-sitrep-13-ncov-v3.pdf (accessed 24 December 2020). 
Wright, A.J., Whitwell, S.C.L., Takeichi, C., Hankins, M., Marteau, T.M. (2009): The impact of numeracy on reactions to different graphic risk presentation formats: an experimental analogue study. British Journal of Health Psychology 14: 107-125. 


\section{Appendix 1: Description of the subjects (additional materal)}

Table S1. Additional characteristics of the participants $(\mathrm{N}=505)$

\begin{tabular}{|l|c|c|c|}
\hline Label & Mean & SD & Range of scale \\
\hline Actively open-minded thinking & 33.51485 & 5.909056 & $7-49$ \\
\hline Belief in conspiracy theories & 28.92079 & 10.63153 & $0-50$ \\
\hline $\begin{array}{l}\text { Statistical numeracy and risk } \\
\text { literacy }\end{array}$ & 3.19604 & 1.959709 & $0-8$ \\
\hline Willingness to think deliberately & 3.475248 & 1.541709 & $0-6$ \\
\hline Willingness to elect & 4.348515 & 1.212257 & $1-5$ \\
\hline Willingness to demonstrate & & & $0-1$ \\
\hline \multicolumn{1}{|c|}{ Climate change } & 0.3445545 & 0.475694 & $0-1$ \\
\hline \multicolumn{1}{|c|}{ Covid-19 } & 0.1584158 & 0.3654925 & $0-1$ \\
\hline
\end{tabular}




\section{Appendix 2: Items and questions of the study}

Table S2a1. Misinformation and factual items about climate change

\begin{tabular}{|c|c|c|c|}
\hline Item no. & Type & Item name & Full text \\
\hline 1 & Misinformation & v17_storyclimate & There is no scientific proof that $\mathrm{CO} 2$ is heating up the atmosphere. \\
\hline 2 & & v18_storyclimate & There is no consensus in science about the causes of climate change. \\
\hline 3 & & v19_storyclimate & Humans are not a major cause of the recent climate change. \\
\hline 4 & & v21_storyclimate & Humans cannot affect the recent climate change. \\
\hline 5 & & v22_storyclimate & $\begin{array}{l}\text { Short-term weather forecasts show that long-term climate models are } \\
\text { inaccurate. }\end{array}$ \\
\hline 6 & & v24_storyclimate & Global warming is mainly driven by the sun. \\
\hline 7 & & v25_storyclimate & $\begin{array}{l}\text { The German government conceals the positive effect of } \mathrm{CO} 2 \text { on plant } \\
\text { growth and thus on the world's food supply. }\end{array}$ \\
\hline 8 & $\begin{array}{l}\text { Factual } \\
\text { information }\end{array}$ & v16_storyclimate & $\begin{array}{l}\text { Climate has changed many times over the millions of years of the earth's } \\
\text { history. }\end{array}$ \\
\hline 9 & & v20_storyclimate & $\mathrm{CO} 2$ makes up only about $0.04 \%$ of the atmosphere \\
\hline 10 & & v23_storyclimate & $\begin{array}{l}\text { Without naturally occurring greenhouse gases (but with otherwise constant } \\
\left.\text { conditions), Earth's average temperature would be near }-18^{\circ} \mathrm{C} \text { [or } 0{ }^{\circ} \mathrm{F}\right] \text {. }\end{array}$ \\
\hline 11 & & v26_storyclimate & $\begin{array}{l}\text { The rate of temperature increase has significantly accelerated over the last } \\
50 \text { years in in Germany (as well as worldwide). }\end{array}$ \\
\hline
\end{tabular}

Table S2a2. Misinformation and factual items about climate change

\begin{tabular}{llll}
\hline Item no. & Type & Mean & Std. Dev. \\
\hline 1 & There is no scientific proof that CO2 is heating up the atmosphere. & 2.946535 & 1.771443 \\
2 & There is no consensus in science about the causes of climate change. & 3.334653 & 1.593914 \\
3 & Humans are not a major cause of the recent climate change. & 2.80396 & 1.659265 \\
4 & Humans cannot affect the recent climate change. & 2.70099 & 1.647418 \\
5 & $\begin{array}{l}\text { Short-term weather forecasts show that long-term climate models are } \\
\text { inaccurate. }\end{array}$ & 3.833663 & 1.682088 \\
6 & Global warming is mainly driven by the sun. & 3.271287 & 1.605937 \\
7 & The German government conceals the positive effect of CO2 on plant & 3.394059 & 1.667013 \\
& growth and thus on the world's food supply. & & \\
\hline
\end{tabular}


Table S2b1. Misinformation and factual items about Covid-19

\begin{tabular}{|c|c|c|c|}
\hline Item no. & Type & Item name & Full text \\
\hline 1 & Misinformation & v28_storycovid & The coronavirus is no more dangerous than seasonal flu. \\
\hline 2 & & v29_storycovid & Microsoft co-founder Bill Gates urges mandatory vaccination of all people. \\
\hline 3 & & v30_storycovid & $\begin{array}{l}\text { There is scientific evidence that mobile phone radiation - including } 5 \mathrm{G} \\
\text { technology - has an effect on the spread of the coronavirus. }\end{array}$ \\
\hline 4 & & v32_storycovid & $\begin{array}{l}\text { Children in Bavaria suffered severe carbon dioxide poisoning while wearing } \\
\text { face masks. }\end{array}$ \\
\hline 5 & & v33_storycovid & $\begin{array}{l}\text { The German government uses the Corona-Warn-App to track contact and } \\
\text { assembly bans. }\end{array}$ \\
\hline 6 & & v35_storycovid & $\begin{array}{l}\text { The wife of Markus Söder, Karin Baumüller-Söder, has generated a revenue } \\
\text { of } 242 \text { million euros in the manufacture and sale of masks in her family } \\
\text { business. }\end{array}$ \\
\hline 7 & & v36_storycovid & $\begin{array}{l}\text { Physicians at the Augsburg University Hospital were paid bonuses if they } \\
\text { reported Covid-19 as the cause of death. }\end{array}$ \\
\hline 8 & $\begin{array}{l}\text { Factual } \\
\text { information }\end{array}$ & v27_storycovid & $\begin{array}{l}\text { The decision as to whether someone has passed away from or with Covid-19 } \\
\text { is not made by the RKI, but by the local public health department. }\end{array}$ \\
\hline 9 & & v31_storycovid & $\begin{array}{l}\text { A suicide, committed by a person not infected with the coronavirus, because } \\
\text { he or she suffered from depression, is not considered in the statistics of } \\
\text { corona deaths. }\end{array}$ \\
\hline 10 & & v34_storycovid & $\begin{array}{l}\text { PCR tests to check whether someone is currently infected with Sars-CoV-2 } \\
\text { do not detect whether or not a person is infectious at the time of the swab. }\end{array}$ \\
\hline 11 & & v37_storycovid & During the coronavirus crisis, the use of alcohol and tobacco increased. \\
\hline
\end{tabular}

Table S2b2. Misinformation and factual items about Covid-19

\begin{tabular}{llll}
\hline Item no. & Type & Mean & Std. Dev. \\
\hline 1 & The coronavirus is no more dangerous than seasonal flu. & 1.910711 \\
2 & Microsoft co-founder Bill Gates urges mandatory vaccination of all people. & 2.968317 & 1.909403 \\
3 & $\begin{array}{l}\text { There is scientific evidence that mobile phone radiation - including 5G } \\
\text { technology - has an effect on the spread of the coronavirus. }\end{array}$ & 1.863366 & 1.338956 \\
& $\begin{array}{l}\text { Children in Bavaria suffered severe carbon dioxide poisoning while } \\
\text { wearing face masks. }\end{array}$ & 2.348515 & 1.659904 \\
& $\begin{array}{l}\text { The German government uses the Corona-Warn-App to track contact and } \\
\text { assembly bans. }\end{array}$ & 3.073267 & 2.081804 \\
& $\begin{array}{l}\text { The wife of Markus Söder, Karin Baumüller-Söder, has generated a } \\
\text { revenue of 242 million euros in the manufacture and sale of masks in her } \\
\text { family business. }\end{array}$ & 3.318812 & 1.743281 \\
& $\begin{array}{l}\text { Physicians at the Augsburg University Hospital were paid bonuses if they } \\
\text { reported Covid-19 as the cause of death. }\end{array}$ & 2.627723 \\
7
\end{tabular}


Table S2c1. Misinformation and factual items about artificial intelligence

\begin{tabular}{|c|c|c|c|}
\hline Item no. & Type & Item name & Full text \\
\hline 1 & Misinformation & v39_ai & $\begin{array}{l}\text { In Germany, artificial intelligence already makes diagnoses in medicine and } \\
\text { independently takes decisions that affect people. }\end{array}$ \\
\hline 2 & & v40_ai & $\begin{array}{l}\text { Artificial intelligence is more and more being used to increase objectivity in } \\
\text { human resources decisions at German universities. }\end{array}$ \\
\hline 3 & & v41_ai & $\begin{array}{l}\text { From road traffic to the classroom: The artificial intelligence-based Dutch } \\
\text { cell phone speed camera is designed to help combat cheating in German } \\
\text { schools and universities. }\end{array}$ \\
\hline 4 & & v43_ai & $\begin{array}{l}\text { The Hotel Bristol Berlin has tested the acceptance of robots at the reception } \\
\text { desk and in the catering area. }\end{array}$ \\
\hline 5 & & v44_ai & $\begin{array}{l}\text { In return for support and consideration in corruption scandals, Volkswagen's } \\
\text { voice assistant recorded information and forwarded it to the federal } \\
\text { government. }\end{array}$ \\
\hline 6 & & v46_ai & $\begin{array}{l}\text { Mickie Krause and Helene Fischer are just two examples: successful singers } \\
\text { are increasingly resorting to artificial intelligence to be in tune with popular } \\
\text { tastes. }\end{array}$ \\
\hline 7 & & v47_ai & $\begin{array}{l}\text { The former world chess champion Garry Kasparov was paid about } 5.5 \\
\text { million euros to lose to Deep Blue, a chess computer developed by IBM. }\end{array}$ \\
\hline 8 & $\begin{array}{l}\text { Factual } \\
\text { information }\end{array}$ & v38_ai & $\begin{array}{l}\text { The Chinese population is monitored and evaluated with the help of artificial } \\
\text { intelligence. }\end{array}$ \\
\hline 9 & & v42_ai & $\begin{array}{l}\text { The founder of Facebook, Mark Zuckerberg, earns billions with the help of } \\
\text { personalized advertising using artificial intelligence. }\end{array}$ \\
\hline 10 & & v45_ai & Stephen Hawking raised the concern that machines could replace humanity. \\
\hline 11 & & v48_ai & $\begin{array}{l}\text { Germany already has ethical rules for the automated and connected vehicle } \\
\text { traffic. }\end{array}$ \\
\hline
\end{tabular}

Table S2b2. Misinformation and factual items about climate change

\begin{tabular}{llll}
\hline Item no. & Type & Mean & Std. Dev. \\
\hline 1 & $\begin{array}{l}\text { In Germany, artificial intelligence already makes diagnoses in medicine } \\
\text { and independently takes decisions that affect people. }\end{array}$ & 3.449505 & 1.535921 \\
2 & $\begin{array}{l}\text { Artificial intelligence is more and more being used to increase objectivity } \\
\text { in human resources decisions at German universities. }\end{array}$ & 3.79802 & 1.375377 \\
3 & $\begin{array}{l}\text { From road traffic to the classroom: The artificial intelligence-based Dutch } \\
\text { cell phone speed camera is designed to help combat cheating in German } \\
\text { schools and universities. }\end{array}$ & 2.788119 & 1.428403 \\
& $\begin{array}{l}\text { The Hotel Bristol Berlin has tested the acceptance of robots at the reception } \\
\text { desk and in the catering area. }\end{array}$ & 3.835644 & 1.422159 \\
4 & $\begin{array}{l}\text { In return for support and consideration in corruption scandals, } \\
\text { Volkswagen's voice assistant recorded information and forwarded it to the } \\
\text { federal government. }\end{array}$ & 2.740594 & 1.601721 \\
&
\end{tabular}




\begin{tabular}{llrl}
\hline 6 & $\begin{array}{l}\text { Mickie Krause and Helene Fischer are just two examples: successful } \\
\text { singers are increasingly resorting to artificial intelligence to be in tune with } \\
\text { popular tastes. }\end{array}$ & 3.085149 & 1.537455 \\
7 & $\begin{array}{l}\text { The former world chess champion Garry Kasparov was paid about 5.5 } \\
\text { million euros to lose to Deep Blue, a chess computer developed by IBM. }\end{array}$ & 3.138614 & 1.614847 \\
\hline
\end{tabular}

Table S3. Subjective Knowledge

\begin{tabular}{|c|c|c|c|}
\hline Type & Variable name & Items & Scale \\
\hline \multirow[t]{5}{*}{$\begin{array}{l}\text { Subjective } \\
\text { Knowledge }\end{array}$} & $\begin{array}{l}\text { v49_sknowclimate, } \\
\text { v54_sknowcovid, } \\
\text { v59_sknowai }\end{array}$ & $\begin{array}{l}\text { I know pretty much about [climate change / Covid-19 / } \\
\text { artificial intelligence]. }\end{array}$ & $\begin{array}{l}1=\text { strongly disagree, } \\
4=\text { neither agree nor } \\
\text { disagree, } 7=\text { strongly agree }\end{array}$ \\
\hline & $\begin{array}{l}\text { v50_sknowclimate, } \\
\text { v55_sknowcovid, } \\
\text { v60_sknowai }\end{array}$ & $\begin{array}{l}\text { I do not feel very knowledgeable about [climate change / } \\
\text { Covid-19/artificial intelligence]. }\end{array}$ & $\begin{array}{l}1=\text { strongly disagree, } \\
4=\text { neither agree nor } \\
\text { disagree, } 7=\text { strongly agree } \\
\text { (reverse scored) }\end{array}$ \\
\hline & $\begin{array}{l}\text { v51_sknowclimate, } \\
\text { v56_sknowcovid, } \\
\text { v61_sknowai }\end{array}$ & $\begin{array}{l}\text { Among my circle of friends, I'm one of the "experts" on } \\
\text { [climate change / Covid-19/ artificial intelligence]. }\end{array}$ & $\begin{array}{l}1=\text { strongly disagree, } \\
4=\text { neither agree nor } \\
\text { disagree, } 7=\text { strongly agree }\end{array}$ \\
\hline & $\begin{array}{l}\text { v52_sknowclimate, } \\
\text { v57_sknowcovid, } \\
\text { v62_sknowai }\end{array}$ & $\begin{array}{l}\text { Compared to most other people, I know less about [climate } \\
\text { change / Covid-19 / artificial intelligence]. }\end{array}$ & $\begin{array}{l}1=\text { strongly disagree, } \\
4=\text { neither agree nor } \\
\text { disagree, } 7=\text { strongly agree } \\
\text { (reverse scored) }\end{array}$ \\
\hline & $\begin{array}{l}\text { v53_sknowclimate, } \\
\text { v58_sknowcovid, } \\
\text { v63_sknowai }\end{array}$ & $\begin{array}{l}\text { When it comes to [climate change / Covid-19 / artificial } \\
\text { intelligence], I really don't know a lot. }\end{array}$ & $\begin{array}{l}1=\text { strongly disagree, } \\
4=\text { neither agree nor } \\
\text { disagree, } 7=\text { strongly agree } \\
\text { (reverse scored) }\end{array}$ \\
\hline
\end{tabular}


Table S4. Willingness to think deliberately (measured via Cognitive Reflection Test)

\begin{tabular}{|c|c|c|c|}
\hline Type & Variable name & Items & Scale/Measurement \\
\hline \multirow[t]{2}{*}{ CRT } & $\operatorname{crt} 1$ & $\begin{array}{l}\text { The ages of Mark and Adam add up to } 28 \text { years total. Mark is } \\
20 \text { years older than Adam. How many years old is Adam? }\end{array}$ & 1 if $, 8^{\prime \prime}, 0=$ else \\
\hline & crt2 & $\begin{array}{l}\text { If it takes } 10 \text { seconds for } 10 \text { printers to print out } 10 \text { pages of } \\
\text { paper, how many seconds will it take } 50 \text { printers to print out } \\
50 \text { pages of paper? }\end{array}$ & 1 if „,10“, $0=$ else \\
\hline & crt3 & $\begin{array}{l}\text { On a loaf of bread, there is a patch of mold. Every day, the } \\
\text { patch doubles in size. If it takes } 40 \text { days for the patch to cover } \\
\text { the entire loaf of bread, how many days would it take for the } \\
\text { patch to cover half of the loaf of bread? }\end{array}$ & 1 if „,39“, $0=$ else \\
\hline & $\operatorname{crt} 4$ & $\begin{array}{l}\text { If you're running a race and you pass the person in second } \\
\text { place, what place are you in? }\end{array}$ & 1 if , $2^{\prime \prime}, 0=$ else \\
\hline & crt5 & A farmer had 15 sheep and all but 8 died. How many are left? & 1 if „, $8 “, 0=$ else \\
\hline & crt6 & $\begin{array}{l}\text { Amelie's father has three daughters. The first two are named } \\
\text { April and May. What is the third daughter's name? }\end{array}$ & 1 if „Amelie“, $0=$ else \\
\hline
\end{tabular}


Table S5. Information avoidance

\begin{tabular}{|c|c|c|c|}
\hline Type & Variable name & Items & Scale/Measurement \\
\hline \multirow[t]{8}{*}{ IA } & $\begin{array}{l}\text { v70_infavclimate, } \\
\text { v78_infavcovid, } \\
\text { v86_infaai }\end{array}$ & $\begin{array}{l}\text { I would rather not know everything about [climate change / } \\
\text { Covid-19 / artificial intelligence]. }\end{array}$ & $\begin{array}{l}1=\text { strongly disagree; } \\
7=\text { strongly agree }\end{array}$ \\
\hline & $\begin{array}{l}\text { v71_infavclimate, } \\
\text { v79_infavcovid, } \\
\text { v87_infaai }\end{array}$ & $\begin{array}{l}\text { I would avoid learning some things about [climate change / } \\
\text { Covid-19 / artificial intelligence]. }\end{array}$ & $\begin{array}{l}1=\text { strongly disagree; } \\
7=\text { strongly agree }\end{array}$ \\
\hline & $\begin{array}{l}\text { v72_infavclimate, } \\
\text { v80_infavcovid, } \\
\text { v88_infaai }\end{array}$ & $\begin{array}{l}\text { Even if it will upset me, I want to know everything about } \\
\text { [climate change / Covid-19 / artificial intelligence]. }\end{array}$ & $\begin{array}{l}1=\text { strongly disagree; } \\
7=\text { strongly agree } \\
\text { (reverse coded) }\end{array}$ \\
\hline & $\begin{array}{l}\text { v73_infavclimate, } \\
\text { v81_infavcovid, } \\
\text { v89_infaai }\end{array}$ & $\begin{array}{l}\text { When it comes to [climate change / Covid-19 / artificial } \\
\text { intelligence], sometimes ignorance is bliss. }\end{array}$ & $\begin{array}{l}1=\text { strongly disagree; } \\
7=\text { strongly agree }\end{array}$ \\
\hline & $\begin{array}{l}\text { v74_infavclimate, } \\
\text { v82_infavcovid, } \\
\text { v90_infaai }\end{array}$ & $\begin{array}{l}\text { I want to know everything about [climate change / Covid-19 } \\
\text { / artificial intelligence]. }\end{array}$ & $\begin{array}{l}1=\text { strongly disagree; } \\
7=\text { strongly agree } \\
\text { (reverse coded) }\end{array}$ \\
\hline & $\begin{array}{l}\text { v75_infavclimate, } \\
\text { v83_infavcovid, } \\
\text { v91_infaai }\end{array}$ & $\begin{array}{l}\text { I can think of situations in which I would rather not know } \\
\text { everything about [climate change / Covid-19/ artificial } \\
\text { intelligence]. }\end{array}$ & $\begin{array}{l}1=\text { strongly disagree; } \\
7=\text { strongly agree }\end{array}$ \\
\hline & $\begin{array}{l}\text { v76_infavclimate, } \\
\text { v84_infavcovid, } \\
\text { v92_infaai }\end{array}$ & $\begin{array}{l}\text { It is important to know everything about [climate change / } \\
\text { Covid-19 / artificial intelligence]. }\end{array}$ & $\begin{array}{l}\text { 1=strongly disagree; } \\
7=\text { strongly agree } \\
\text { (reverse coded) }\end{array}$ \\
\hline & $\begin{array}{l}\text { v77_infavclimate, } \\
\text { v85_infavcovid, } \\
\text { v93_infaai }\end{array}$ & $\begin{array}{l}\text { I want to know new information about [climate change / } \\
\text { Covid-19 / artificial intelligence] immediately. }\end{array}$ & $\begin{array}{l}1=\text { strongly disagree; } \\
7=\text { strongly agree } \\
\text { (reverse coded) }\end{array}$ \\
\hline
\end{tabular}


Table S6. Beliefs in conspiracy theories

\begin{tabular}{llll}
\hline Type & Variable name & Items & Scale/Measurement \\
\hline IA & v94_conspir & $\begin{array}{l}\text { I think that many very important things happen in the world, } \\
\text { which the public is never informed about. }\end{array}$ & $\begin{array}{l}0(0 \%-\text { certainly not }) \text { to } 10 \\
(100 \%-\text { certain })\end{array}$ \\
\hline v95_conspir & $\begin{array}{l}\text { I think that politicians usually do not tell us the true motives } \\
\text { for their decisions. }\end{array}$ & $\begin{array}{l}0(0 \%-\text { certainly not }) \text { to } 10 \\
(100 \%-\text { certain })\end{array}$ \\
\hline v96_conspir & I think that government agencies closely monitor all citizens. & $\begin{array}{l}0(0 \%-\text { certainly not }) \text { to } 10 \\
(100 \%-\text { certain })\end{array}$ \\
\hline v97_conspir & $\begin{array}{l}\text { I think that events which superficially seem to lack a } \\
\text { connection are often the result of secret activities. }\end{array}$ & $\begin{array}{l}0(0 \%-\text { certainly not }) \text { to } 10 \\
(100 \%-\text { certain })\end{array}$ \\
\hline
\end{tabular}


Table S7. Actively open-minded thinking (AOT)

\begin{tabular}{|c|c|c|c|}
\hline Type & Variable name & Items & Scale/Measurement \\
\hline \multirow[t]{7}{*}{ AOT } & v99_AOT & $\begin{array}{l}\text { Allowing oneself to be convinced by an opposing argument } \\
\text { is a sign of good character. }\end{array}$ & $\begin{array}{l}1=\text { completely disagree, } \\
4=\text { neutral, } 7=\text { completely } \\
\text { agree }\end{array}$ \\
\hline & v100_AOT & $\begin{array}{l}\text { People should take into consideration evidence that goes } \\
\text { against their beliefs. }\end{array}$ & $\begin{array}{l}1=\text { completely disagree, } \\
4=\text { neutral, } 7=\text { completely } \\
\text { agree }\end{array}$ \\
\hline & v101_AOT & $\begin{array}{l}\text { People should revise their beliefs in response to new } \\
\text { information or evidence. }\end{array}$ & $\begin{array}{l}\text { 1=completely disagree, } \\
4=\text { neutral, } 7=\text { completely } \\
\text { agree }\end{array}$ \\
\hline & v102_AOT & Changing your mind is a sign of weakness. & $\begin{array}{l}\text { 1=completely disagree, } \\
4=\text { neutral, } 7=\text { completely } \\
\text { agree } \\
\text { (reverse coded) }\end{array}$ \\
\hline & v103_AOT & Intuition is the best guide in making decisions. & $\begin{array}{l}1=\text { completely disagree, } \\
4=\text { neutral, } 7=\text { completely } \\
\text { agree } \\
\text { (reverse coded) }\end{array}$ \\
\hline & v104_AOT & $\begin{array}{l}\text { It is important to persevere in your beliefs even when } \\
\text { evidence is brought to bear against them. }\end{array}$ & $\begin{array}{l}\text { 1=completely disagree, } \\
4=\text { neutral, } 7=\text { completely } \\
\text { agree } \\
\text { (reverse coded) }\end{array}$ \\
\hline & v105_AOT & $\begin{array}{l}\text { One should disregard evidence that conflicts with one's } \\
\text { established beliefs. }\end{array}$ & $\begin{array}{l}1=\text { completely disagree, } \\
4=\text { neutral, } 7=\text { completely } \\
\text { agree } \\
\text { (reverse coded) }\end{array}$ \\
\hline
\end{tabular}


Table S8. Risk perception

\begin{tabular}{|c|c|c|c|}
\hline Type & Variable name & Items & Scale \\
\hline \multirow[t]{4}{*}{$\mathbf{R P}$} & $\begin{array}{l}\text { v106_riskclimate, } \\
\text { v110_riskcovid, } \\
\text { v114_riskai }\end{array}$ & $\begin{array}{l}\text { [climate change / Covid-19 / artificial intelligence] represents } \\
\text { an issue where I am personally worried. }\end{array}$ & $\begin{array}{l}1=\text { strongly disagree, } \\
4=\text { neither agree nor } \\
\text { disagree, } 7=\text { strongly agree }\end{array}$ \\
\hline & $\begin{array}{l}\text { v107_riskclimate, } \\
\text { v111_riskcovid, } \\
\text { v115_riskai }\end{array}$ & $\begin{array}{l}\text { [climate change / Covid-19 / artificial intelligence] poses a } \\
\text { big threat to society. }\end{array}$ & $\begin{array}{l}1=\text { strongly disagree, } \\
4=\text { neither agree nor } \\
\text { disagree, } 7=\text { strongly agree }\end{array}$ \\
\hline & $\begin{array}{l}\text { v108_riskclimate, } \\
\text { v112_riskcovid, } \\
\text { v116_riskai }\end{array}$ & $\begin{array}{l}\text { It is too early to say whether [climate change / Covid-19 / } \\
\text { artificial intelligence] is really a problem. }\end{array}$ & $\begin{array}{l}\text { 1=strongly disagree, } \\
4=\text { neither agree nor } \\
\text { disagree, } 7=\text { strongly agree } \\
\text { (reverse scored) }\end{array}$ \\
\hline & $\begin{array}{l}\text { v109_riskclimate, } \\
\text { v113_riskcovid, } \\
\text { v117_riskai }\end{array}$ & $\begin{array}{l}\text { I personally have no disadvantages from [climate change / } \\
\text { Covid-19 / artificial intelligence]. }\end{array}$ & $\begin{array}{l}\text { 1=strongly disagree, } \\
4=\text { neither agree nor } \\
\text { disagree, } 7=\text { strongly agree } \\
\text { (reverse scored) }\end{array}$ \\
\hline
\end{tabular}


Table S9. Risk literacy

\begin{tabular}{|c|c|c|c|}
\hline Type & Variable name & Items & Scale/Measurement \\
\hline \multirow[t]{8}{*}{ Num } & numeracy_1 & $\begin{array}{l}\text { Imagine we are throwing a five-sided die } 50 \text { times. On } \\
\text { average, out of these } 50 \text { throws how many times would this } \\
\text { five-sided die show an odd number }(1,3 \text { or } 5) \text { ? }\end{array}$ & 1 if " 30 ", $0=$ else \\
\hline & numeracy_2 & $\begin{array}{l}\text { Out of } 1,000 \text { people in a small town } 500 \text { are members of a } \\
\text { choir. Out of these } 500 \text { members in the choir } 100 \text { are men. } \\
\text { Out of the } 500 \text { inhabitants that are not in the choir } 300 \text { are } \\
\text { men. What is the probability that a randomly drawn man is a } \\
\text { member of the choir? Please indicate the probability in } \\
\text { percent. }\end{array}$ & 1 if " 25 ", $0=$ else \\
\hline & numeracy_3 & $\begin{array}{l}\text { Imagine we are throwing a loaded die ( } 6 \text { sides) } 70 \text { times. The } \\
\text { probability that the die shows a } 6 \text { is twice as high as the } \\
\text { probability of each of the other numbers. On average, out of } \\
\text { these } 70 \text { throws, how many times would the die show the } \\
\text { number } 6 \text { ? }\end{array}$ & 1 if " 20 ", $0=$ else \\
\hline & numeracy_4 & $\begin{array}{l}\text { In a forest } 20 \% \text { of mushrooms are red, } 50 \% \text { brown and } 30 \% \\
\text { white. A red mushroom is poisonous with a probability of } \\
20 \% \text {. A mushroom that is not red is poisonous with a } \\
\text { probability of } 5 \% \text {. What is the probability that a poisonous } \\
\text { mushroom in the forest is red? }\end{array}$ & 1 if " 50 ", $0=$ else \\
\hline & numeracy_5 & $\begin{array}{l}\text { Imagine that we flip a fair coin } 1,000 \text { times. What is your best } \\
\text { guess about how many times the coin would come up heads } \\
\text { in } 1,000 \text { flips? }\end{array}$ & 1 if " $500 ", 0=$ else \\
\hline & numeracy_6 & $\begin{array}{l}\text { In a scratch card lottery, the chance of winning a } € 10 \text { prize on } \\
\text { the card is } 1 \% \text {. What is your best guess about how many } \\
\text { people would win a } € 10 \text { prize if } 1,000 \text { people each buy a } \\
\text { single scratch card? }\end{array}$ & 1 if " $10 ", 0=$ else \\
\hline & numeracy_7 & $\begin{array}{l}\text { At a raffle, the chance of winning a car is } 1 \text { in } 1,000 \text {. What } \\
\text { percentage of tickets in the raffle win a car? }\end{array}$ & 1 if “ 0.1 ", $0=$ else \\
\hline & numeracy_8 & $\begin{array}{l}\text { What represents the highest chance of something happening: } \\
1 \text { in } 10,1 \text { in } 1000 \text {, or } 1 \text { in } 100 ?\end{array}$ & 1 if " 1 in $10 ", 0=$ else \\
\hline
\end{tabular}


Table S10. Socio-demographic variables and items and activities

\begin{tabular}{|c|c|c|c|}
\hline Type & Variable name & Items & Scale \\
\hline \multirow[t]{5}{*}{$\begin{array}{l}\text { Socio- } \\
\text { demographic } \\
\text { predictors }\end{array}$} & v138_Happiness & $\begin{array}{l}\text { Now, we would like to ask you about your satisfaction with } \\
\text { your life in general. Please answer using the following } \\
\text { scale, in which } 0 \text { means completely dissatisfied and } 10 \\
\text { means completely satisfied. How satisfied are you at } \\
\text { present with your life as a whole?" }\end{array}$ & $\begin{array}{l}0=\text { completely dissatisfied, } \\
\ldots, \quad 10=\text { completely } \\
\text { satisfied }\end{array}$ \\
\hline & v135_right & $\begin{array}{l}\text { In politics people often talk about "left" and "right" to } \\
\text { distinguish different attitudes. If you think about your own } \\
\text { political views: Where would you place them? Please } \\
\text { answer using the following scale. } 0 \text { means "entirely left", } \\
10 \text { means "entirely right". }\end{array}$ & $\begin{array}{l}0=\text { entirely left, } \\
10=\text { entirely right }\end{array}$ \\
\hline & v15_age & How old are you? & \\
\hline & v14_education & Please indicate your highest level of education. & $\begin{array}{lr}\text { 1=(not yet) } & \text { graduated, } \\
2=\text { graduated } & \text { from } \\
\text { secondary } & \text { school, } \\
3=\text { graduded } & \text { from high } \\
\text { school or } & \text { similar, } \\
\text { 4=general or } & \text { specialized } \\
\text { university } & \text { entrance } \\
\text { qualification, } & \text { 5=gradued } \\
\text { from } & \text { university } \\
\text { (Bachelor), 6=gradued } \\
\text { from university (Master, } \\
\text { Magister, } \\
\begin{array}{l}\text { Staatsexamen), Diplom, } \\
7=\text { doctoral degree }\end{array}\end{array}$ \\
\hline & v13_male & What is your gender? & $\begin{array}{l}1=\text { Female }, \quad 2=\text { Male, } \\
3=\text { Other }\end{array}$ \\
\hline \multirow[t]{3}{*}{ Activities } & $\begin{array}{l}\text { v143_democlimate, } \\
\text { v_144_democovid, } \\
\text { v_145_demoai }\end{array}$ & $\begin{array}{l}\text { Have you ever joined a demonstration addressing the } \\
\text { following issues? } \\
\text { [climate change / Covid-19 / artificial intelligence] }\end{array}$ & $\begin{array}{l}0=\mathrm{No}, \text { out of question, } \\
1=\mathrm{No} \text {, but I can imagine to } \\
\text { do / Yes }\end{array}$ \\
\hline & v142_intendelect & Do you plan to vote in the next federal election? & $\begin{array}{l}1=\text { No, } \quad 2=\text { Probably no, } \\
3=\text { Unsure, } \quad 4=\text { Probably } \\
\text { yes, } 5=\text { Yes }\end{array}$ \\
\hline & $\begin{array}{l}\text { v132_networkclimate, } \\
\text { v133_networkcovid, } \\
\text { v134_networkai }\end{array}$ & $\begin{array}{l}\text { How often do you use social networks (such as Facebook } \\
\text { or Twitter) to inform yourself / communicate about the } \\
\text { following topics? } \\
\text { [climate change / Covid-19 / artificial intelligence] }\end{array}$ & $\begin{array}{l}\text { 1=Never, } 2=\text { Less } \\
\text { frequently, } 3=\text { Once a } \\
\text { month, 4=Several times a } \\
\text { month, 5=Once a week, } \\
6=\text { Several times a week, } \\
7=\text { Daily, } 8=\text { Several times } \\
\text { a day }\end{array}$ \\
\hline
\end{tabular}


Table S11. Trust

\begin{tabular}{llll}
\hline Type & Variable name & Items & Scale/Measurement \\
\hline $\mathbf{T}$ & v119_trustdemocr & $\begin{array}{l}\text { How much do you trust each of the following? -- Democracy } \\
\text { in our country }\end{array}$ & $\begin{array}{l}1=\text { cannot be trusted at all } \\
\text { to } 7=\text { can be trusted a lot }\end{array}$ \\
\hline v120_science & How much do you trust each of the following? -- Science & $\begin{array}{l}1=\text { cannot be trusted at all } \\
\text { to } 7=\text { can be trusted a lot }\end{array}$ \\
\hline v121_trustmedia & $\begin{array}{l}\text { How much do you trust each of the following? -- Information } \\
\text { from mass media (e.g. newspapers, television, radio) }\end{array}$ & $\begin{array}{l}1=\text { cannot be trusted at all } \\
\text { to } 7=\text { can be trusted a lot }\end{array}$ \\
\hline & v122_trustnetwork & $\begin{array}{l}\text { How much do you trust each of the following? -- Information } \\
\text { from social networks (e.g. Facebook, Twitter) }\end{array}$ & $\begin{array}{l}1=\text { cannot be trusted at all } \\
\text { to 7=can be trusted a lot }\end{array}$ \\
\hline
\end{tabular}

